
EDUCATORS DURING THE COVID-19 PANDEMIC: HIGHLIGHTING SOCIAL (IN)JUSTICE

Nevashnee Perumal, Roshini Pillay, Zibonele France Zimba, Mbongeni Sithole, Marichen van der Westhuizen, Priscalia Khosa, Thanduxolo Nomngcoyiya, Malebo Mokone, Uwarren September

Dr Nevashnee Perumal, Nelson Mandela University, Gqeberha, South Africa.

Dr Roshini Pillay, University of the Witwatersrand, Johannesburg, South Africa.

Dr Zibonele France Zimba, Stellenbosch University, Stellenbosch, South Africa.

Dr Mbongeni Sithole, University of KwaZulu-Natal, Durban, South Africa.

Prof. Marichen van der Westhuizen, University of the Western Cape, Bellville, South Africa.

Ms Priscalia Khosa, Stellenbosch University, Stellenbosch, South Africa.

Dr Thanduxolo Nomngcoyiya, University of Fort Hare, Alice, South Africa

Ms Malebo Mokone, University of Limpopo, Polokwane, South Africa.

Mr Uwarren September, University of the Western Cape, Cape Town, Bellville, South Africa.

Nevashnee Perumal: nevashnee.perumal@ mandela.ac.za

Roshini Pillay: Roshini.Pillay@wits.ac.za

Zibonele France Zimba: zfzimba@sun.ac.za

Mbongeni Sithole: SITHOLEM3@ukzn.ac.za

Marichen van der Westhuizen: mvanderwesthuizen@uwc.ac.za

Priscalia Khosa PRISCALIA@sun.ac.za

Thanduxolo Nomngcoyiya: TNomngcoyiya@ufh.ac.za

Malebo Mokone: malebo.mokone@ul.ac.za

Uwarren September: useptember@uwc.ac.za

COVID-19 has exposed the inequalities and polarisation of South African communities and institutions of higher learning on the continuum of privilege. As nine social work educators, we share our reflections on how we traversed the higher education space during the beginning of the pandemic, using an autoethnography lens, with the pedagogy of discomfort and critical social work theory as the threads in the complex tapestry of our stories. We describe our orientations as social work educators, the successes, challenges, and recommendations on reimagining and reframing learning and teaching in relation to student-institutional relationships, boundaries and support. 


\title{
AUTOETHNOGRAPHIC VIEW OF SOUTH AFRICAN SOCIAL WORK EDUCATORS DURING THE COVID-19 PANDEMIC: HIGHLIGHTING SOCIAL (IN)JUSTICE
}

\author{
Nevashnee Perumal, Roshini Pillay, Zibonele France Zimba, Mbongeni Sithole, Marichen van der \\ Westhuizen, Priscalia Khosa, Thanduxolo Nomngcoyiya, Malebo Mokone, Uwarren September. \\ Dr Nevashnee Perumal, Nelson Mandela University, Gqeberha, South Africa. \\ Dr Roshini Pillay, University of the Witwatersrand, Johannesburg, South Africa. \\ Dr Zibonele France Zimba, Stellenbosch University, Stellenbosch, South Africa. \\ Dr Mbongeni Sithole, University of KwaZulu-Natal, Durban, South Africa. \\ Prof. Marichen van der Westhuizen, University of the Western Cape, Bellville, South Africa. \\ Ms Priscalia Khosa, Stellenbosch University, Stellenbosch, South Africa. \\ Dr Thanduxolo Nomngcoyiya, University of Fort Hare, Alice, South Africa \\ Ms Malebo Mokone, University of Limpopo, Polokwane, South Africa. \\ Mr Uwarren September, University of the Western Cape, Cape Town, Bellville, South Africa.
}

\section{INTRODUCTION}

Collaboration, support and the development of a community of practice are essential and meaningful in finding hope during a period of disaster such as the COVID-19 pandemic. In this autoethnographic article, nine educators employed at various higher education institutions in South Africa, from historically advantaged to disadvantaged, give reflective accounts of how we dealt with emotions ranging from anger and outrage, to a sense of helplessness, at the injustice of the roll-out of emergency remote online learning and teaching (EROLT). The very notion of differential segregation and stratification of institutions of higher learning along various dimensions that existed before COVID-19 also compounded the situation - for instance, the divide between rural and urban-based universities in terms of access to resources, as well as the structural and focal differences between research-intensive, comprehensive universities and universities of technology. In the main, online learning was viewed as a solution, despite the related concerns.

In our professional roles as social work academics, we are guided by the following definition of social work, as propounded by the International Federation of Social Workers (IFSW) and International Association of Schools of Social Work (IASSW) in 2014 (IFSW, 2021):

Social work is a practice-based profession and an academic discipline that promotes social change and development, social cohesion, and the empowerment and liberation of people. Principles of social justice, human rights, collective responsibility and respect for diversities are central to social work. Underpinned by theories of social work, social sciences, humanities and indigenous knowledge, social work engages people and structures to address life challenges and enhance wellbeing.

Because the definition of social work becomes a part of a social worker's DNA, we could not spectate and suffocate while injustices were perpetuated against students and colleagues. Hence, we assumed collective responsibility as a community of social work academics to speak out in the social work academic arena and then put on paper the meaning we made of EROLT as the pandemic in South Africa began. We exposed our vulnerabilities and beliefs in the hope that, as we worked within a digitally divided society, we could strive to uphold a sense of care for the wellbeing of students and colleagues. The use of EROLT made us revisit where we came from, why we teach social work and the roles that we play in the spaces that we occupy. Social injustice, human rights violations, inequity and poverty are some of the aspects that disturbed and discomforted us during this process. 
COVID-19 is not just a health concern; it affects social, psychological and financial wellbeing. While life came to a halt in China early in 2020, where the first case and the rapid spread of the coronavirus were identified, countries worldwide followed with varying lockdown measures (Mashitoa, 2020; Peters, Wang, Ogunniran, Huang, Green, Hunga, Quainooi, Ren, Hollings, Mou, Khomera, Zhang, Zhou, Laimeche, Zheng, Xu, Jackson \& Hayes, 2020). COVID-19 was declared a global pandemic in March 2020 (World Health Organization, 2020) and governments globally took drastic steps to impose a lockdown in order to save lives, which led to the disruption of all systems, including higher education and training (Ali, 2020; Dispatchlive, 2020; Faraj, 2020; United Nations Educational, Scientific and Cultural Organization, 2020). South Africa's first COVID-19 case was reported in March 2020, and on 15 March 2020 a national state of disaster was declared, followed by a national lockdown on 26 March 2020 (Dispatchlive, 2020; Mhlanga \& Moloi, 2020). These actions resulted in a shutdown of all higher education institutions and a complete disruption of the academic programme, with a move to EROLT.

Against the backdrop of an unequal society, where there are huge disparities in South Africa between rich and poor post-democracy (Soudien, Reddy \& Woolard, 2019), the pivot to EROLT accentuated social injustice and inequity (Czerniewicz, 2018; 2020). Moreover, the move to EROLT occurred within a context that was both complex and arduous because of existing issues of poor living conditions, high data costs, limited bandwidth and psychosocial factors that adversely affect students from lower socioeconomic groups (Motala \& Menon, 2020; Wangenge-Ouma \& Kupe, 2020).

While scientists raced to find a vaccine and to understand the pandemic, there was a spread of literature on COVID-19 and how it negatively affected various facets of society, and specifically students (BehariLeak \& Behari, 2020; Motala \& Menon, 2020; Mpungose, 2020; Wilson, Tan, Knox, Ong, Crawford \& Rudolph, 2020). The focus of studies on the impact of adopting EROLT has predominantly been on capturing students' voices and reporting on how these changes affected them (Armstrong-Mensah, Ramsey-White, Yankey \& Self-Brown, 2020; Mashitoa, 2020; Peters et al., 2020). However, the voices of South African social work educators have been silent, which is the gap that this article intends to fill.

EROLT was unevenly delivered because of the divergent speeds at which universities were able to respond to the disruption caused by the pandemic (Kajiita, Nomngcoyiya \& Kang'ethe, 2020; Motala \& Menon, 2020; Wangenge-Ouma \& Kupe, 2020). The injustice was magnified by the hastily developed measures taken to save the 2020 academic year. While this paper speaks about our experiences from the start of lockdown in 2020, our reflections include an awareness of how past injustices and inequality continue to affect the current situation. Our discomfort, with roots going back to before the pandemic, persists. Therefore, voicing our stories in this article is not only a way of showing our frustrations at how EROLT unfolded, but is also an opportunity for us to articulate our tacit knowledge as social work educators based on our lived experiences during the pandemic.

\section{APPROACH AND METHOD}

This article employs the methodological approach of autoethnographic research. We are not anthropologists; we are social workers teaching social work in higher education and training. Autoethnography enables first-person narratives, self-observation and self-reflection on the author's experiences (Adams, Holman Jones \& Ellis, 2015). Zawadzki and Jensen (2020) argue that autoethnography is a relatively new design fuelled by the postmodern period (1990-1995). "The essence of postmodernism is that many ways of knowing and inquiring are legitimate and that no one way should be privileged" (Wall, 2006:2). It is a design, involving personal autoethnographic narratives, which facilitates an understanding of the activities in which one participates. We chose this approach because autoethnography is considered to be a design with emancipatory drives, and is pursued by researchers expressing critical feelings regarding particular issues of power (Jones \& Pruyn, 2018; Zawadzki \& Jensen, 2020).

In this study, we analyse self-observational empirical material through the lens of the pedagogy of discomfort and critical social work theory. Anderson (2006) argues that autoethnographic inquiry follows

Social Work/Maatskaplike Werk 2021:57(4) 
several rules that legitimise an analytical autoethnographic inquiry. Firstly, complete member researcher (CMR) status: auto-ethnographers must orient themselves (at least for significant periods of time) to documenting and analysing action as well as purposively engaging in it. Secondly, analytical reflexivity: autoethnographers-as-authors frame their accounts with personal reflexive views of the self. Their ethnographic data are situated within their personal experience and sense-making, and researchers should attempt to scrutinise the interaction between them, the environment and other social factors. Thirdly, narrative visibility of the researcher's self is paramount: to be visible and active in the text is attained by providing a plot and the opportunity for the reader to understand the story empathically (Zawadzki \& Jensen, 2020). Finally, commitment to theoretical analysis, the defining characteristic of analytical social science, involves the use of empirical data to gain insight into a broader set of social phenomena than those provided by the data themselves. Zawadzki and Jensen (2020) add that the analysis of empirical data should apply to a wider set of social phenomena.

In retrospect, and following the steps suggested by Anderson (2006) regarding an autoethnographic inquiry, we initially collaborated as concerned colleagues to formulate a statement on the implications of EROLT for social work education. As social work educators from seven South African universities, we came together in solidarity, acutely aware of our privileges or lack thereof in our work spaces. We composed a statement for onward submission to our professional body to give expression to the injustices perpetrated against students and educators during this pandemic. Through our collaborative efforts, we observed a common thread in our experiences, consistent with the IFSW definition of social work, namely a concern with social justice, our wellbeing and the wellbeing of students. Therefore, nine of us share our reflections on how we traversed the higher education space during the initial stages of the pandemic. We construct our narrative from personal experiences of how COVID-19 impacted on our personal as well as professional lives. Central to these personal experiences is the influence of our underlying values and beliefs.

\section{THEORETICAL FRAMEWORK}

As concerned social work educators representing diverse educational contexts, we explored a variety of theories and pedagogical approaches to guide our reflections. We identified the pedagogy of discomfort (Zembylas \& McGlynn, 2012) and critical social work theory (Hurley \& Taiwo, 2019) as most suitable to guide the interpretation of our reflections. The pedagogy of discomfort is a social justice education approach arguing that discomforting feelings are important when challenging dominant discourses that sustain inequalities (Boler \& Zembylas, 2003). Transformation towards social justice is the aim of this pedagogy. Berlak (2004, as cited in Zembylas, 2015:164), asserts that, if a major purpose of social justice education is to unsettle cherished beliefs about the world, then some discomfort is not only unavoidable but also necessary. Zembylas (2015) further postulates that when teaching engenders some sort of crisis in the student, and when this is done with care regarding students' wellbeing, then there is potential for transformation.

Dutta, Shroll, Engelsen, Prickett, Hajjar and Green, (2016) concur that one can support the transformation to address inequalities and injustices through the discomfort of moving outside of one's comfort zone. In South Africa the inequalities that remain between students at institutions of higher education are underpinned by socio-economic factors, stemming from the apartheid era. This requires a movement away from mere acknowledgment in policy documents to a discussion of how transformation can take place, and what is needed for it to take place, resulting in practical projects (Costandius \& Alexander, 2019). It was therefore necessary to give expression to our personal experiences as centred in our differing academic contexts. In this article, we acknowledge that such inequalities still exist among higher education institutions, and that epistemological transformation is needed to address these inequalities.

Critical social work theory evolves from critical reflections. It questions past and current ways of perceiving and stimulates a discourse on what would be relevant in a specific context at a specific point in time. This theory is compatible with the pedagogy of discomfort as it aims to address those structural barriers that sustain injustices (Hurley \& Taiwo, 2019). Both the pedagogy of discomfort and critical 
social work theory are thus appropriate for the analysis we present in this paper. Together they provided a lens through which we reflected on our experiences during the COVID-19 pandemic. We challenged the assertion that universities must continue to operate according to 'business as usual' practices, while most students from disadvantaged backgrounds fell behind in their curricula. We placed the spotlight on the layered injustices at disadvantaged universities which struggle to support students because of their limited resources and an inadequate infrastructure to deliver EROLT. We questioned how the wellbeing of students and staff was taken into account during the pandemic, and how the failure to acknowledge the inequalities between students and universities was perpetuating instead of addressing inequalities. We also questioned how the needs of students and the requirements of emergency online learning and teaching impacted on educators. Through our reflections, we attempted to create a space of discomfort to critically reflect on what is needed for the transformation towards a socially just system where students and staff experience equity and where universities strive for social justice.

\section{AUTOETHNOGRAPHIC REFLECTIONS}

Our reflections encapsulate the description of self, our reasons for teaching social work, the roles we play in the spaces that we occupy, and our solidarity in efforts to promote social justice while maintaining ethical care during our engagements with students, colleagues, friends and families. To uphold the principles of honesty and authenticity that are congruent with autoethnography, the authors use their real names as identification.

\section{The paradox of 'saving the academic year' amid the COVID-19 pandemic}

Following the COVID-19 outbreak, the academic sector came up with strategies to address the pandemicrelated challenges. In pursuit of 'saving the academic year', the system accelerated the shift to online learning in a 'quick fix' manner, without regard for long-term impact. While the conversation regarding EROLT became critical for educators like myself, drastically shifting to the level of readiness for the implementation of EROLT, it was concerning that this conversation appeared to overlook the plight of students caught amidst this situation. From the outset, it became apparent that the socio-economic background of the majority of students was going to be the main determinant of how quickly the institutions of higher learning responded to pandemic-related challenges.

I regard myself as a social work educator who is concerned about critical reflection and student and staff wellbeing. I also teach because I wish to contribute to the change in students' socio-economic circumstances. In advancing their circumstances, students started sending messages pleading their socioeconomic circumstances, which boiled down to their further marginalisation. These concerns could not be overlooked, at least when it comes to social work educators, as they motivated the need to collaborate with other like-minded peers with a view to making the silent voices of students and educators heard. The very notion of differential segregation and stratification of institutions of higher learning along various dimensions, which existed before COVID-19, also compounded the situation. For instance, some are separated along a geographical dimension (rural-based against urban-based), some are categorised as research-intensive against comprehensive universities and universities of technology. In the main, online learning was viewed as a solution, despite the related concerns. In the process, practical support, contextual realities and how previous marginalisation and injustices impacted on students were ignored. The plight of students appeared to be reduced to the mere access to devices, data and connectivity or lack thereof.

The learning and teaching reality, in particular, not only for students but for some lecturers as well, tended to involve the need to juxtapose different related challenges, namely the existence of the pandemic, lack of resources and lack of expertise to undertake online learning. Overriding all three challenges has been the issue of the socio-economic circumstances characterising the majority of the students. While the academic year may appear to have been saved, I am concerned about the long-term impact. Perhaps, going forward, there is a need to centralise critical reflection as well as student and staff wellbeing when measures of EROLT are devised. (Mbongeni Sithole)

Social Work/Maatskaplike Werk 2021:57(4) 


\section{From thinking and saying, to reflecting and sharing, to doing and changing}

Our discussions started with one comment by a colleague who raised a concern about our ability to engage with the rapid change to emergency online learning and teaching, while also being affected by the pandemic on a personal level. Random comments followed, and then the shift came when a group decided to further explore what this would mean for social work education in South Africa going forward. I experienced this first comment as a perfect example of raising discomfort, people responding and subsequent critical reflection.

Further focused discussions were based on a collaborative approach to search for meaning based on our experiences. We were able to draw a link between our wellbeing and the wellbeing of our students. We could share what we were doing to manage, and also what our institutions were doing to support our efforts. Much was said in the media about how the pandemic highlighted the ongoing inequalities in South African society, including inequalities in higher education. Representing the different institutions, we could openly engage in discussions regarding what it means, and critically reflect on how we, as social work educators, respond to social injustices experienced in our context of higher education. For me, the commitment to verbalise not only our concerns, but also sharing lessons learned, gave value to my participation. Through our initial exploration of our own diverse experiences, and our commitment to sharing this to stimulate ongoing discussion, I believe we contribute by asking ourselves: What is needed from us to operationalise social justice? For me, transformation starts through such discussions, but it has to go further. Our discussions identified structural changes in higher education to ensure equal and socially just sharing of resources, transformative supportive education frameworks for disadvantaged students, and ongoing discourses to include the voices of social work educators and students in institutional planning as aspects that need attention for transformation to take place. (Marichen van der Westhuizen)

\section{There is power in my voice, I shall not mute!}

Ten years as an academic, in the Eastern Cape, I was shaken by the inequalities, inequities, poverty and desperation, especially of the student and academic communities. Higher education is unequal in so many ways, with students travelling from all parts of the country and Africa, not enough student accommodation available, resulting in an array of associated social dynamics, sharing rooms, notes, food, devices, dense course content in an unfamiliar language, and the list continues. Basically, every other student is assisting another student so that they can reach the graduation finishing line. Therefore, when we were mandated to move learning and teaching online due to COVID-19, it was unjust to shift students from campuses and leave them to learn on their own.

In addition to having no peer support, they shoulder the burden to give hope to their families back home by getting a university degree. As a first-generation graduate, this resonated deeply with me. For me to keep quiet in an environment where I teach social justice would be gravely unjust. I was not prepared to begin teaching online without letting the powers that be know that remote online teaching was not fair to students, or to academics. Having utilised all available spaces to raise my voice, I still had to run the academic programme online.

This was very difficult as I had not actively used online methods before. I struggled to record narrations on slides. One lecture had to be cut into at least seven pieces to fit the space that was allowed, taking five hours of preparation. Students then accessed that 'dumped' content only when assessments were due. This use of the learning management system was counterproductive to lifelong learning. I was frustrated because students were suffering and my hands were tied! My colleagues were also suffering the consequences of this mode of teaching. They were sharing devices at home, often with their children who were learning online; they are living in areas that have network and connectivity challenges; they are caring for ageing parents as well as living with comorbidities themselves. How can this mode of teaching be fair and just? I do not doubt that the opportunities inherent in the remote online platform are vast, if we are able to better coordinate nationally, to stop what we are doing and to deliberate on how to make this work, with the student voices reigning supreme. After all, the students are the ones being assessed 
on their learning; shouldn't they tell us how to teach them? I fear that we are losing great opportunities to harness indigenous ways of learning and teaching by restricting ourselves to online, unequal methods only. (Nevashnee Perumal)

\section{Conflicted emotions and questions about principles of social justice, human rights and collective responsibility}

I recall with a great sense of clarity the first moments when the first positive case of coronavirus hit the headlines in South Africa. A few days later the President of the Republic spoke and we were heading for total lockdown. Most universities ordered students to vacate residences and return home for the lockdown to ensure their safety. It was not clear what would happen to academic activities. There was an immediate sense of urgency from universities to come up with a plan on business continuity under lockdown. My university was swift to act. Monitoring the fluidity of the ever-evolving situation, my university made the decision to move to online learning and closed its university buildings. I'll not deny that this concerned me. My concerns were, firstly, I had no knowledge and experience of comprehensive online teaching and learning, and secondly, the technological and connectivity challenges my students were likely to encounter; and lastly, the high levels of socio-economic issues that would hamper students' participation during the process of online teaching and learning.

My reflection is based on these three concerns. As we continued with online teaching and learning, it was difficult to learn about online learning as I had limited knowledge and experience of this methodology. Daily, students were sending emails informing me that they could not respond to online activities because of a lack of technological devices and poor connectivity. Some students would inform me that their parents, or someone who provides support, had lost their job and their family could not function normally. During this experience I had conflicting emotions and questions about principles of social justice and human rights. I became a social worker to fight for social justice. Yet during the COVID-19 pandemic universities have been slow to respond to the abnormalities and injustices perpetuated by the pandemic. Being a social work educator, I had to ask myself what it means in action to fight for social justice, human rights, taking collective responsibility, and respect for the diversity central to social work, and approved by the IFSW General Meeting and the IASSW General Assembly in July 2014. (Zibonele Zimba)

\section{Striving for social justice during the COVID-19 pandemic}

I teach social work because I would like to influence the calibre of social workers who practise in South Africa and internationally, so that they can effect positive change in people's lives. Given that the key function of social work is to promote social justice and social change whilst enhancing human capabilities and wellbeing, in my teaching I strive to ensure that students are equipped with relevant social work knowledge, skills and competencies. Moreover, in my teaching, I strive to create a learning environment where students can form connections and engage critically with social issues facing South Africa. My teaching philosophy is based on the principles of adult learning in which I see students as collaborative partners in their learning. However, this was difficult to achieve at the beginning of the pandemic and the imposed lockdown. Although my workload mainly focused on supervising Masters' students who were learning remotely prior to the pandemic, it was challenging to maintain contact with all students, because everyone had to adapt to working from home while managing various other roles.

As a social work educator, I strive for social justice. Hence, I was open and willing to engage with fellow academics who are not only interested in teaching and research, but are also concerned about the wellbeing of students. This is particularly vital during the COVID-19 pandemic which has exposed the already existing inequalities within the South African higher education sector. Higher education institutions, by their very nature, are highly stressful environments, focused on knowledge creation and the production of holistic and well-balanced graduates for social and economic development. With COVID-19, most black and poor students, who have historically been the victims of social inequalities on campuses, have become socially disconnected by the move to remote learning, unable to connect with 
lecturers and classmates, which further widens the existing social, economic and technological divisions and disparities. Historically disadvantaged universities are worse off given that they are dealing with several challenges, where a significant number of students who come from marginalised communities are exposed to poor information technology (IT) infrastructure and experience electricity constraints, especially those students located in rural areas. This, in turn, has led to some of the historically disadvantaged institutions lagging in delivering emergency online learning, compared to the situation in historically advantaged institutions. This is the reality of the South African higher education landscape which is influenced by social, political and economic inequalities based on class, race, gender, and the location of institutions. (Priscalia Khosa)

\section{COVID-19 and EROLT exposed the existing inequalities and social injustices in higher education}

I teach social work because it is a profession that is strongly rooted in the tenets of human rights, social justice, equity and equality, and promotes the recognition of the value, worth and dignity of all people. We acknowledge that much has been achieved in the 27 years of the democratic dispensation in terms of trying to level the playing field socially, economically and politically, among other aspects of people's lives. However, the COVID-19 pandemic has once more exposed the huge inequalities, the social injustices and the human rights violations that exist, not only socially and economically, but also in our higher education system. This exposure occurred when our government enforced EROLT on the entire education system, thus creating a two-tier education system. As usual, this gave an unfair advantage to already privileged institutions to continue with their teaching and learning, leaving many students from the historically disadvantaged institutions and communities behind and confused, as they were not ready and/or did not have the requisite resources to continue with their education.

While we live in the era of the Fourth Industrial Revolution, or we have become a society that lives in a technologically oriented epoch, I have never thought that our current government would allow any undertaking to continue without considering fundamental values of human rights, equality, equity and social justice in the higher education system. This is rather unfortunate as the creation of a two-tier higher education system between the historically advantaged and disadvantaged institutions runs counter to the country's gains since the advent of the democratic dispensation in 1994. This, in my view, perpetuates the social injustices and inequalities that students from disadvantaged communities have had to endure over many decades of the apartheid system. I believe it will take more than just the provision of emergency online teaching and learning devices and data by the state to bridge the huge gaps that exist between these two-tiers of the higher education system in this country. The decision to opt for EROLT only served the interests of the few at the expense of the majority of poor people in this country and it is a decision that will go down in history as one of the moments when, once again, history has repeated itself. In my capacity as a black radical social worker and educator, I feel justified to at least raise my voice rather than keeping quiet, so continuing to be part of the society and system that condones the social injustices and inequalities our people are subjected to in the name of keeping the ball rolling in the higher education system of our country. (Thando Nomngcoyiya)

\section{Trying to breathe during EROLT}

I teach to make a small difference in South Africa. The pivot to EROLT in May 2020 was experienced by me as shallow breathing, similar to the way that the COVID-19 virus attacks your respiratory system and compromises the life force in the body - the breath. I had to understand the type of access my students had, because online teaching would be useless without access to data, Wi-Fi and hardware. Fortunately, the university was able to loan students devices and offer them some data. It was sad to note that these measures were not consistently applied in all higher education institutions. More shallow breaths were taken as a result of the unevenness of the roll-out process.

While I acknowledge the affordances of blended learning, EROLT exists in a context of a broken learning ecosystem. From the onset of EROLT, educators scurried to make sense of the process and learnt from various sources while they were teaching. Course design and content were altered to ensure that 
synchronous and asynchronous methods were used. The work days blurred into the evenings and the weekends. I was cloistered within my home. Work-life balance was non-existent.

Roles merged and transformed. My roles included: teacher, wife, colleague, mother, $1^{\text {st }}$-year theory coordinator, sister, Chair of Teaching and Learning in the School of Human and Community Development, friend, grieving friend, research supervisor, neighbour, member of a group of concerned social work educators, aunt and member of an online support group for educators teaching group work.

These roles offered me multiple perspectives on life during the pandemic. These roles taught me that care and empathy were important considerations. I realised that life is precious and we need to breathe while meeting various demands. COVID-19 has changed how teaching and learning occurs. The inequality of teaching using EROLT was socially unjust. This group of educators offered me support during the pandemic. (Roshini Pillay)

\section{Teaching and learning in the midst of COVID-19: inequality exacerbated}

Graduating with a Bachelor of Arts in Social Work and an Honours degree from a historically disadvantaged university, and using these qualifications as a stepping stone to acquiring a Master's degree from a university abroad, taught me that your background and where you study do not determine where you land in life. My experiences motivated me to dedicate the past 33 years of my life to contributing towards addressing the inequalities in our society through training social workers who are willing to challenge injustice. The majority of our students come from predominantly poor families and under-resourced communities, but they graduate and excel in the field of social work and various occupations they pursue. I have always been committed to contributing to training social workers who not only understand global issues, but are rooted in the critical application of indigenous knowledge systems as well as understanding the dynamics in communities and are committed to fighting for social justice.

The COVID-19 pandemic, and the drastic regulations that were promulgated to deal with it, exposed the inequalities in the institutions of higher learning in South Africa, despite 26 years of democracy. When the state of disaster was declared, universities had to shut down, with serious ramifications for all. They were thrust into the world of remote online teaching and learning. This new way of teaching and learning created serious challenges for staff and students at historically disadvantaged universities which, unlike the historically advantaged universities, had to speedily adapt to using technology for teaching. Most academics underwent training in the use of Blackboard while catching up on teaching. Some staff members and the majority of students did not have laptops, which compounded their problems. Furthermore, students had to adapt from contact to remote online teaching and learning, while contending with challenges associated with a lack of resources, including data or internet connectivity, coupled with challenging home circumstances. Both staff and students experienced personal and academic challenges such as blurring of work and personal space, and coping with health and financial challenges which negatively impacted on teaching and learning. As social work educators, we noted that management of institutions of higher learning and the Department of Higher Education, Science and Technology pushed to save the academic year despite the experiences of staff and students. This encouraged me to join colleagues in voicing our discomfort by raising awareness, so that the Department of Higher Education, Science and Technology should support institutions to develop intervention strategies and deadlines which are informed by their realities so that no student is left behind. (Malebo Mokone)

\section{The impact of COVID-19 on my teaching and learning as a social work educator}

In the turmoil of COVID-19, lecturers are experiencing extraordinary challenges, including the interruption of established educational programmes and routines, the quick shift from face-to-face teaching to online teaching, the emotional toll of isolation because of social distancing requirements, and uncertainty about one's personal safety and health. 
The unexpectedness of lockdown left very little time for me as a lecturer to lay the groundwork to teach students online and for students to learn online. The conversion of modules from face-to-face teaching to online teaching revealed a new level of under-preparedness in lecturing. As an academic, I had to acquire new skills and reflect on the changes required. I also continued with my research studies, and constantly engaged with other lecturers on teaching and learning issues. Having to multitask in addition to managing my personal life and my work took its toll on me, as important decisions had to be made, and online teaching was taking a lot of time. Being adaptive and flexible during this immense disruption of teaching and learning was very important and required me as a lecturer to be open-minded and creative in my teaching. Lessons can become routine very quickly, especially when students are left to learn in an open method. In a short space, I had to think innovatively and redesign an online teaching schedule. Making sure that learning never stopped, I also needed to make sure that the quality of learning did not deteriorate. The constant reminder during COVID-19 is that online teaching needs to remain studentcentred.

Caring and support had to be normalised, given that the emotional impact of the pandemic was inescapable. Personal and social challenges arose and needed to be addressed in my own family environment, and the constant need for psychosocial support of students remained. I had to spend time giving such psychosocial support and alleviating the fears of students arising from the online teaching and learning approach, as well as the socio-economic circumstances. Communication was also critical for many reasons. There was no method that one could work from for online teaching and not being able to make use of the well-established processes and procedures of the university required constant communication with all students. An essential step was also listening and responding. Communication had to be educational, repeated and, at the same time, calm. I experienced feelings of anxiety because of the lack of being in contact with people, technological difficulties and ineffective communication. Another concern was worrying that online teaching could have an impact on the effectiveness of my own studies.

COVID-19 has given rise to exceptional challenges as well as opportunities. In my experience, adapting theoretical lessons by making them more practical and the use of online tools served to maximise online engagement with students. Even though not perfect yet, this is a practical strategy for interacting and communicating with students. From this experience, I realised that there is still much more to be done before classroom face-to-face lessons can be entirely replaced with online teaching and learning. (Uwarren September)

\section{DISCUSSION}

As socially conscious social work educators representing diverse educational contexts, and with a strong will to uphold social justice, we coupled autoethnography with the pedagogy of discomfort and critical social work theory as the most suitable methodology to frame our reflections of teaching, learning and living during COVID-19. Acknowledging that we need to make our voices heard, we intentionally pursued autoethnography because it is emancipatory and provides room for expressing critical feelings on particular issues of power (Jones \& Pruyn, 2018; Zawadzki \& Jensen, 2020). A restless tension, brought on by the glaring injustices of EROLT at the onset of the pandemic, descended upon us. In our conversations as EROLT was unfolding, we could not keep quiet and remain complicit while observing the social injustices against disadvantaged students and fatigued academic staff.

We recognise our privilege of occupying academic positions, which are inherently powerful, yet our own disadvantages within this position of power are also very real. We confronted issues such as not being able to readily deliver EROLT because we lacked the skill set, the devices and sufficient connectivity at resource-scarce institutions. In addition, our own living conditions, reduced work-life boundaries and mental health were strained during this period. Feelings of discomfort and agitation began suffocating us, so we used the pedagogy of discomfort to frame our reflections. We concur that a social justice educational approach acknowledges that discomforting feelings are important when challenging dominant discourses that sustain inequalities (Boler \& Zembylas, 2003). We recognise the progress made 
by South Africa's transition to democracy and the many gains to redress the structural imbalances, but we would be remiss not to also register our discomfort and feelings of betrayal in structures, as evidenced in our reflections.

The chasm of inequalities that still exists between students at institutions of higher education is rooted in socio-economic factors prevailing since the apartheid era (Spaull, 2013). The two-tier education system of advantaged and disadvantaged institutions was given renewed life during the COVID-19 period, and politicians irresponsibly touted the Fourth Industrial Revolution as an opportunity for education, when in our country the digital divide between privilege and poverty widened. Berlak (2004, as cited in Zembylas, 2015:164) asserts that if a major purpose of social justice education is to unsettle cherished beliefs about the world, then some discomfort is not only unavoidable but also necessary. Dutta et al. (2016) concur that one can support the transformation process to address inequalities and injustices through the discomfort of moving outside of one's comfort zone. As a collective, committed to transformative socially just education, we intentionally decided not to dilute our voices with those of several authors from other publications as reference points. Here, we share our experiences in our own voices, asserting the power of voice.

As Mbongeni Sithole says:

While this conversation about EROLT became critical for educators like me, it was even more concerning that it appeared to be the overlooking of the plight of students amid this situation and that the conversation drastically shifted from the level of readiness of how EROLT had to be done. From that very onset, it became apparent that the socio-economic background of the majority of students was going to be the main determinant on how quickly the institutions of higher learning responded to pandemic-related challenges.

Sithole's words echo the shock and dismay we felt when confronted by the inequalities, inequities, poverty, and desperation of the communities at large, but more especially the student and academic communities. We also express our displeasure about the move of higher education to EROLT in response to COVID-19 without due regard for the socio-economic circumstances of the majority of students. We see this as history repeating itself because poor students now seem to be experiencing the same challenges we experienced during apartheid. In addition, EROLT distanced students from each other, yet we know that during contact teaching and learning, students do support each other in the spirit of ubuntu, so that they can reach the finish line.

Similarly, other reflections reveal their concerns with COVID-19, as most black and poor students, who have historically been the victims of social inequalities on campuses, have become socially disconnected by the move to EROLT, unable to connect with lecturers and peers, which widens the existing social, economic and technological divisions and disparities further. We register our deep concerns about the desperate situation of disadvantaged universities who are worse off given that they are dealing with several challenges, where a significant number of students from marginalised communities are exposed to poor IT infrastructure, and experience electricity constraints, especially those located in rural areas. Furthermore, an extension of the ethic of care underpinned our practice where our role extended beyond just being educators. We became counsellors who spent time giving psychosocial support and alleviating the fears of students stemming from EROLT, aggravated by COVID-19. As human beings, we too had to deal with feelings of anxiety, being distanced from our collegial and family support, facing technological difficulties, and having to deal with ineffective communication.

As we provide these significant and unique voices of reason on the rollout of EROLT in South Africa, we cannot help but appreciate the strong influence of the pedagogy of discomfort and critical social work theory as the combined guiding theoretical lens for conveying our thoughts and experiences in this article. Together they provided a lens through which we, as social work educators, reflected on our experiences during the COVID-19 pandemic and challenged the assertion that universities must continue to operate from a standpoint of 'business as usual', while most students from disadvantaged backgrounds continued 
to be left behind, and previously disadvantaged universities struggled to support disadvantaged students despite the limited resources available for the rollout of EROLT.

\section{Conclusion and recommendations}

Inherent in the definition of social work is the notion that social justice, human rights, collective responsibility and respect for diversities are key principles central to social work (IFSW, 2021). As educators within a community of practice, we took a collective responsibility to offer our views on EROLT (Lave, 1991). We found it befitting to advocate and uphold these principles enshrined in the definition of social work to ensure that every author's voice is given equal status. In contrast to the acquisition of knowledge and a teacher-learner dyad, reflections in this article developed as part of a relational participation in social communities, which is about learning together and from each other (Pyrko, Dörfler \& Eden, 2017).

Participation in a community of practice with other academic voices on the impact of EROLT during COVID-19 served to develop insight into the impact of this pandemic in higher education. Our reflections revealed an increased workload and poor recognition of wellbeing for educators and students. With EROLT, work-life balance became a myth. We cannot stop learning and teaching, but we ought to be responsible, just, ethical and aware of how we deliver learning in a South African context, keeping in mind the current realities of inequalities.

In the words of Marichen van der Westhuizen:

There is a need for rapid structural changes; equitable sharing of resources; ongoing discourses in transformative education frameworks; and amplifying social work educator and student voices in institutional planning.

Our conclusions led to the following recommendations, which we will present together with our motivations:

Social justice has to do with principles of fairness, equity, inclusion and equality. Future trends require educators to be vigilant to guard against income and gender inequality and widening of the digital divide amongst students and between the different HEI's in South Africa. These principles support the operationalising of social justice and placing human rights at the centre. Therefore we recommend that:

- Research is undertaken in terms of student access and student success to warrant different ways to disrupt the structural inequalities;

- There is a national collaborative advocacy network of all universities and their students which enable fair and equitable distribution of resources as a long-term outcome;

- All academics, support staff and students collaborate in developing EROLT pedagogical tools and skills that support learning for student success. Because many students and staff are struggling alone and feel isolated through EROTL, this will assist in building critical thinking skills amongst students and create a community practice beyond online teaching and learning;

- The lack of resources at historically disadvantaged institutions is addressed immediately to close the inequalities gap between South African universities. COVID-19 has demonstrated that adopting a long-term approach to addressing inequalities is no longer an option;

- There is fair discrimination in respect of resource allocation to historically disadvantaged South African universities. This allocation of resources should also include students from lower socioeconomic backgrounds who are studying in advantaged institutions. Doing this will realise the principle of equity.

The lessons learned during the pandemic must be used to guide transformation processes in higher education and in institutions generally. With a specific focus on social work education and training, we share a commitment not only to teach the principles of social justice, human rights, collective 
responsibility and respect for diversity, but also to actively promote them in practice. In this regard, we recommend that:

- Authentic inclusive national conversations are initiated with student populations on the EROLT rollout to address their concerns and hear their voices;

- Transformational processes should centre the voices of academic, administrative staff and students in institutional planning to ensure that changes are made to learning and teaching;

- Education and training includes a deep reflection by social work departments regarding their position and roles in higher education institutions on the implementation of institutional transformation agendas. This will require active and continued critical reflection, embedded in the pedagogy of discomfort and the ethic of care which is intended to result in epistemological transformation;

- Further research be conducted on managing in higher education during crises and pandemics.

Diversity must be foregrounded and valued, and collective decision making should be actively practised, so that:

- The historical influences on the wellbeing on the South African peoples, as well as the socioeconomic injustices that continue to exist, are challenged and addressed. In this way, a fair and just society can be built within the higher education context;

- There is a disruptive reconceptualisation of geographical boundaries that separate students. This will ensure greater access to resources and facilities.

To recognise the wellbeing of educators, students and support staff as critical to academic success, we recommend that:

- The biopsychosocial wellbeing of educators, students and support staff be placed on the agenda of all higher education institutions to ensure that students and staff will flourish;

- There should be better understanding of increased workload for educators when using EROLT approaches which impact on work-life balance negatively.

\section{REFERENCES}

ADAMS, T. E., HOLMAN JONES, S. \& ELLIS, C. 2015. Autoethnography. Oxford: Oxford University Press.

ALI, W. 2020. Online and remote learning in higher education institutes: A necessity in light of COVID19 pandemic. Higher Education Studies, 10(3): 16-25.

ANDERSON, L. 2006. Analytic autoethnography. Journal of Contemporary Ethnography, 35(4): 373-395.

ARMSTRONG-MENSAH, E., RAMSEY-WHITE, K., YANKEY, B. \& SELF-BROWN, S. 2020. COVID-19 and distance learning: Effects on Georgia State University School of Public Health students. Frontiers in Public Health, 8: 576227.

BEHARI-LEAK, K. \& BEHARI, S. 2020. Leadership amidst the COVID-19 crisis: Exploring a curriculum for Servant Leadership in HE and beyond. In: Teaching and Learning in Higher Education in the Time of COVID-19, Vol. 3, 187-209. CSSALL Publishers.

BERLAK, A. 2020.Confrontation and pedagogy: Culturl secrets and emotion in antioppresiive pedagogies. In: BOLER, M. (ed.). Democratice dialogue in education: Troubling speech, disturbing silence: 123-144. New York: Peter Lang. 
BOLER, M. \& ZEMBYLAS, M. 2003. Discomforting truths: The emotional terrain of understanding differences. In: TRIFONAS, P. (ed.). Pedagogies of difference: Rethinking education for social justice. New York: Routledge.

COSTANDIUS, E. \& ALEXANDER, N. 2019. Exploring shame and pedagogies of discomfort in critical citizenship education. Transformation in Higher Education, 4(0): 1-8.

CZERNIEWICZ, L. 2018. Inequality as higher education goes online. In: DOHN, N.B., CRANMER, S., SIME, J.A., DE LAAT, M. \& RYBERG, E. (eds.). Networked learning: reflections and challenges. Berlin/Heidelberg, Germany: Springer.

CZERNIEWICZ, L. 2020. What we learnt from 'going online' during university shutdowns in South Africa. PhilonEdTech, March 15. [Online] Available: https://philonedtech.com/what-we-learnt-fromgoing-online-during-university-shutdowns-in-south-africa/ [Accessed: 17.07.2021].

DISPATCHLIVE. 2020. Full speech: President Ramaphosa on South Africa's answer to Covid-19. [Online] Available: https://www.dispatchlive.co.za/news/2020-03-15-full-speach-president-ramaphosaon-COVID- 19/ [Accessed: 17.07.2021].

DUTTA, U., SHROLL, T., ENGELSEN, J., PRICKETT, S., HAJJAR, L. \& GREEN, J. 2016. The "messiness" of teaching/learning social (in)justice: Performing a pedagogy of discomfort. Qualitative Inquiry, 22(5): 345-352.

FARAJ, G. 2020. The impact of COVID-19 on universities in Africa. ACCORD, October 21. [Online] Available: $\quad$ https://www.accord.org.za/analysis/the-impact-of-covid-19-on-universities-in-africa/ [Accessed: 17.07.2021].

HURLEY, D. \& TAIWO, A. 2019. Critical social work and competency practice: A proposal to bridge theory and practice in the classroom. Social Work Education, 38(2): 198-211.

INTERNATIONAL FEDERATION OF SOCIAL WORKERS (IFSW). 2021. Global definition of social work. [Online] Available: https://www.ifsw.org/what-is-social-work/global-definition-of-socialwork/ [Accessed: 17.07.2021].

JONES, S.H. \& PRUYN, M. (eds.). 2018. Creative selves/creative cultures: Critical autoethnography, performance, and pedagogy. Cham: Palgrave Macmillan.

KAJIITA, R. M., NOMNGCOYIYA, T. \& KANG'ETHE, S. M. 2020. The 'revolution' on teaching and learning: Implications of COVID-19 on social work education in institutions of higher learning in Africa. African Journal of Social Work, 10(3): 25-33.

LAVE, J. 1991. Situating learning in communities of practice. Perspectives on socially shared cognition. In: RESNICK, L.B., LEVINE, J.M. \& TEASLEY, S.D. (eds.). Perspectives on socially shared cognition. Washington, DC: American Psychological Association.

MASHITOA, J. 2020. Voices of business studies students on Virtual Learning Environments (VLE) during COVID-19 lockdown in one university in South Africa. Journal of African Education, 1(3): 7186.

MHLANGA, D. \& MOLOI, T. 2020. COVID-19 and the digital transformation of education: What are we learning on 4IR in South Africa? Education Sciences, 10(7): 180.

MOTALA, S. \& MENON, K. 2020. In search of the 'new normal': Reflections on teaching and learning during COVID-19 in a South African university. Southern African Review of Education, 26(1): 8099.

MPUNGOSE, C. B. 2020. Emergent transition from face-to-face to online learning in a South African university in the context of the Coronavirus pandemic. Humanities and Social Sciences Communications, 7: 113. 
406

PETERS, M. A., WANG, H., OGUNNIRAN, M. O., HUANG, Y., GREEN, B., CHUNGA, J. O., QUAINOOI, E. A., REN, Z., HOLLINGS, S., MOU, C., KHOMERA, S. W., ZHANG, M., ZHOU, S., LAIMECHE, A., ZHENG, W., XU, R., JACKSON, L. \& HAYES, S. 2020. China's internationalized higher education during Covid-19: Collective student autoethnography. Postdigital Science and Education, 2: 968-988.

PYRKO, I., DÖRFLER, V. \& EDEN, C. 2017. Thinking together: What makes communities of practice work? Human Relations, 70(4): 389-409.

SOUDIEN, C., REDDY, V. \& WOOLARD, I. (eds.). 2019. Poverty \& inequality: Diagnosis prognosis responses. Cape Town: HSRC Press.

SPAULL, N. 2013. Poverty \& privilege: primary school inequality in South Africa. International Journal of Educational Development, 33(5): 436-447.

UNITED NATIONS EDUCATIONAL, SCIENTIFIC AND CULTURAL ORGANIZATION (UNESCO). 2020. COVID-19 educational disruption and response. [Online] Available: COVID-19 Educational Disruption and Response (unesco.org) [Accessed: 17.07.2021].

WALL, S. 2006. An autoethnography on learning about autoethnography. International Journal of Qualitative Methods, 5(2): 1-12

WANGENGE-OUMA, G. \& KUPE, T. 2020. Uncertain times: Re-imagining universities for new, sustainable futures. Pretoria: Universities of South Africa.

WILSON, S., TAN, S., KNOX, M., ONG, A., CRAWFORD, J. \& RUDOLPH, J. 2020. Enabling crosscultural student voice during COVID-19: A collective autoethnography. Journal of University Teaching and Learning Practice, 17(5): 1-21.

WORLD HEALTH ORGANIZATION (WHO). 2020. WHO Director-General's opening remarks at the media briefing on COVID-19 - 11 March 2020. [Online] Available: https://www.who.int/directorgeneral/speeches/detail/who-director-general-s-opening-remarks-at-the-media-briefing-on-covid-19--11-march-2020 [Accessed: 19.03.2020].

ZAWADZKI, M. \& JENSEN, T. 2020. Bullying and the neoliberal university: A co-authored autoethnography. Management Learning, 51(4): 398-413.

ZEMBYLAS, M. 2015. 'Pedagogy of discomfort' and its ethical implications: The tensions of ethical violence in social justice education. Ethics and Education, 10(2): 163-174.

ZEMBYLAS, M. \& MCGLYNN, C. 2012. Discomforting pedagogies: Emotional tensions, ethical dilemmas and transformative possibilities. British Educational Research Journal, 38(1):41-59. 